\title{
In vitro anthelmintic activity and phytochemical characterization of Corallocarpus epigaeus (Rottler) Hook. f. tuber from ethyl acetate extracts
}

\author{
Kalpesh B. Ishnava* (D) and Priya S. Konar
}

\begin{abstract}
Background: Helminth infections occur in poverty-stricken areas and developing countries with warm and humid environments and where sanitary conditions are poor. Only few drugs are regularly used for the treatment of these parasite infections.

Results: For checking the anthelmintic activity, taking Corallocarpus epigaeus extracts and their composition was done using organic solvents, namely methanol, chloroform, ethyl acetate and hexane against Pheretima posthuma (earthworms). Four different concentrations $(25,50,75$, and $100 \mathrm{mg} / \mathrm{ml}$, respectively) while normal saline and albendazole $(20 \mathrm{mg} / \mathrm{ml})$ were taken as the control and standard drug, respectively. Time of paralysis and death of the worms were determined. The result depict that the ethyl acetate extract showed finest activity. The minimum inhibition concentration (MIC) was found out to be $12.5 \mathrm{mg} / \mathrm{ml}$ against albendazole drug $(20 \mathrm{mg} / \mathrm{ml})$. The preliminary phytochemical qualitative analysis of the promising ethyl acetate extract showed the presence of alkaloid, flavonoid, saponin, phenol, tannins and steroids. HPTLC analysis of ethyl acetate extract showed 6 bands. GC-MS results analysis of ethyl acetate extract showed 6 bands, the identified compounds were $n$-hexadecanoic acid and octadecanoic acid.
\end{abstract}

Conclusion: Identified bioactive compounds were $n$-hexadecanoic acid and 1-octadecanoic acid which may be useful for the treatment of helminthiasis.

Keywords: Corallocarpus epigaeus, Tuber, Anthelmintic activity, Phytochemical analysis, HPTLC, GC-MS

\section{Highlights}

- Anthelmintic activity of the C. epigaeus, extraction was done using organic solvents, namely methanol, chloroform, ethyl acetate, and hexane against Pheretima posthuma (earthworms).

- Yield obtained from methanol, chloroform, ethyl acetate, and hexane were $4.02 \%, 2.62 \%, 4.46 \%$ and $3.89 \%$, respectively.

- Four different concentrations $(25,50,75$, and $100 \mathrm{mg} / \mathrm{ml}$ ) were taken from the extracts and normal

\footnotetext{
* Correspondence: ishnavakb203@yahoo.com

Ashok and Rita Patel Institute of Integrated Studies and Research in Biotechnology and Allied Sciences (ARIBAS), New Vallabh Vidyanag, Anand, Gujarat ar-388121, India
}

saline was taken as the control and albendazole as the standard drug.

- Time of paralysis and death of the worms were determined. The result depicted that the ethyl acetate extract showed finest activity.

- The minimum inhibition concentration was found out to be $12.5 \mathrm{mg} / \mathrm{ml}$. The preliminary phytochemical qualitative analysis of the ethyl acetate extract showed the presence of alkaloid, flavonoid, saponin, phenol, tannins, and steroids.

- Thin layer chromatography was carried out using different solvent system among which toluene:methanol:ethyl acetate in the ratio of 8:2:1 showed good separation for the ethyl acetate extract. 
- This system was used for the further analysis by HPTLC method. HPTLC analysis of ethyl acetate extract showed 6 bands.

- GC-MS results analysis of ethyl acetate extract showed 6 peaks and major identified bioactive compound was $n$-hexadecanoic acid and octadecanoic acid.

- This compound may be useful for the treatment of Helminthiasis.

\section{Introduction}

Numerous helminth contaminations happen in destitution-stricken territory and creating nations with warm and muggy situations and where clean conditions are poor. Today, it is assessed that roughly $33 \%$ of the individuals in creating locales of sub-Saharan Africa, Asia, and America are contaminated by helminthes (Hotez and Herricks, 2015). The World Health Organization reports that $35 \%$ diseases are because of roundworm, which is a typical parasitic worm. More than 1.5 billion individuals or $24 \%$ of the total population are tainted with soil-transmitted helminth contaminations around the world (WHO, 2016).

Despite this pervasiveness of parasitic diseases, the examination on anthelmintic medication is insufficient. According to WHO, just couple of medications are consistently utilized for the treatment of these parasite diseases (Chandan et al., 2011). Nonetheless, the devices we at present have for controlling worm diseases are restricted to just four medications. Albendazole, oxamniquine, piperazine, and ivermectin were created to treat helminthiasis (Chirac and Torreele, 2006).Together with diethylcarbamazine and mebendazole, these medications speak to nearly our whole pharmacopeia for battling the most well-known contaminations on the planet (Peter et al., 2008). Helminth diseases ordinarily found in cows can be moved from creature to man; this is known as zoonosis.

The activity of any anthelmintic medication is to either deaden or kill the worm and oust from the body. A portion of the usually accessible medications are albendazole, mebendazole, piperazine thiabendazole and levamisole (Stephenson et al., 1989; Marco et al., 1994; Albonico et al., 2003). Industrially accessible anthelmintics turned into a serious issue around the world. Various restorative plants have been utilized to treat parasitic contaminations in man and creatures. A few investigations have demonstrated that plant species can viably decrease the level of parasite invasion in animals and are promising options in contrast to ordinary anthelmintics that are both reasonable and ecologically worthy (Vidyadha et al., 2010). It has been recorded that conventional healers use plant prescriptions, which give social insurance to $80 \%$ of the human populace over a billion people (Kuldeep and Rahul, 2013). Home-grown drugs possess stood the trial of energy for their wellbeing, adequacy, agreeableness and lesser reactions (Subha et al., 2006).

Corallocarpus epigaeus (Rottler) Hook. f. (Cucurbitaceae) is locally known as Jungli suran, and is distributed in tropical and temperate regions of India, Ceylon, Deccan, and South Maratha country. Plant is monoecious, leaves sinuately 3 lobed, calyx lobes lanceolate, corolla dull or greenish yellow, fruit ovoid or ellipsoid, beaked, red except for the greenish base and portion of beak which is $2.5-5-\mathrm{mm}$ long and flowers, and fruiting period June-October (Pandey et al., 2005). The root contains a bitter principle allied to bryonin. A phydroxybenzoyl ester, named epigaeusyl ester, group of terpenoids sesquiterpene lactones viz. corallocarpscalaride, a pyridine carboxylic ester, designated as corallocarpeonyl ester (Ishnava et al., 2015). Different activity of C. epigaeus is reported for different diseases like antifungal (Vasantha et al., 2012), antibacterial (Priyavardhini et al., 2012), anticancer (Bhavani and Leelavathi, 2012), antidiabetic (Gnananath et al., 2013), and antioxidant (Thangavel et al., 2014). The earthworms have been used for the initial evaluation of anthelmintic compounds in vitro. Because of its anatomically and physiological resemblance with the intestinal roundworm parasite of human beings and easy availability. Among the elective techniques, there has been impressive and growing enthusiasm for conventional home-grown deformers in both created and creating nations. Henceforth, the best option is plant-based prescription (Robert et al., 2009). The plants are known to give a rich wellspring of herbal anthelmintics. Ideally, an anthelmintic agent should have broad spectrum of action, high percentage of cure with a single therapeutic dose, free-form toxicity to the host, and should be cost effective. None of the synthetic drugs available meets this requirement (Nisha et al., 2012). Therefore, the present work aims to study the in vitro anthelmintic activity and phytochemical characterization of Corallocarpus epigaeus and their extracts using different organic solvents.

\section{Material and methods \\ Plant material}

Corallocarpus epigaeus (Rottler) Hook. f. (Cucurbitaceae) plant species was collected from the Virpur village in Gujarat in the month of June 2016 (Fig. 1). The tuber of healthy and disease-free plants were used to test the medicinal properties of the plant. The plant specimens (ARIBASKBI-1) were identified by Dr. Kalpesh Ishnava (Plant Taxonomist) at Ashok and Rita Patel Institute of Integrated Study and Research in Biotechnology and Allied Sciences (ARIBAS), New Vallabh Vidhyanagar, Gujarat, India.

\section{Preparation of the extracts}

The collected plant materials (tubers) were washed in running tap water and dried. It was then grinded properly, 


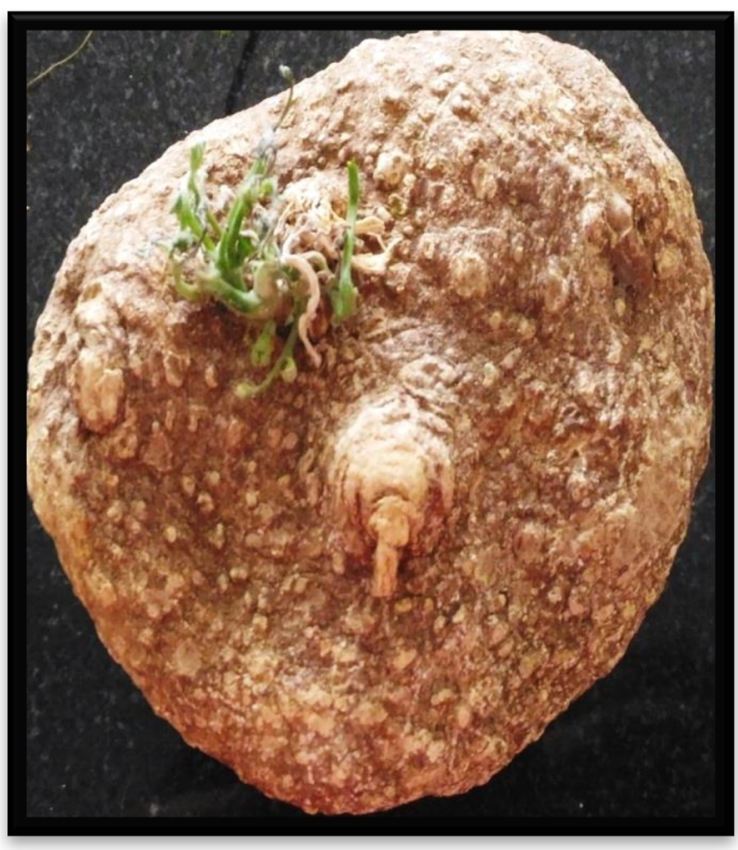

Fig. 1 Tuber of Corallocarpus epigaeus (Arn.) Cl

and then the powder was sieved with a commercial sieve of mesh size approximately $60 \mathrm{~mm}$ to make the particle size uniform and labeled and stored in airtight bottles for further use. Extracts were prepared using exact weighed sample powder $(50 \mathrm{~g})$ in the measured volume of solvents $(250 \mathrm{ml})$ each separately like methanol, chloroform, ethyl acetate, and hexane. Extraction was carried out using Soxhlet extraction method and solvent is poured into the round-bottom extraction flask, weighed and placed on the heating mantle. After this, the thimble containing the sample powder $(50 \mathrm{~g})$ was placed into the extraction chamber. Lastly, the condenser was placed on top of the extraction flask and all these parts were fixed vertically. Plant extracts were prepared using four different extracting solvents (methanol, chloroform, ethyl acetate, and hexane) separately (Harborne, 1973).

\section{Phytochemical screening}

Qualitative assay and quantitative assay for the presence of plant phytoconstituents such as alkaloids, glycosides, flavonoids, phenol, tannins, and saponins were carried out using standard procedure (Harborne, 1973; Parekh and Chanda, 2008).

\section{Collection of animal and experiment}

The assay was performed on adult earthworm owing to its anatomical and physiological resemblance with the intestinal roundworm parasites of human beings. Easy availability of earthworms prompts their extensive use for preliminary in-vitro evaluation of anthelmintic compounds.

Methanol, chloroform, ethyl acetate, and hexane extracts of tuber powder of Corallocarpus epigaeus were investigated for their anthelmintic activity against earthworm. All the test solutions and standard drug solutions were prepared freshly before starting the experiment. Three groups of earthworms of approximately equal size were released in to $20 \mathrm{ml}$ solutions of 4 different concentrations $(25,50,75,100 \mathrm{mg} / \mathrm{ml})$ in Petri dishes containing above solutions of extracts. Albendazole $(20 \mathrm{mg} / \mathrm{ml})$ was used as reference standard and saline as control. Determination of time of paralysis and time of death of the worm were done. Time for paralysis was noted when no movement of any sort could be observed except when the worms were shaken vigorously. Time for death of worms was recorded after ascertaining that worms neither moved when shaken vigorously.

\section{Thin layer chromatography}

The above prepared plant extracts were applied on precoated TLC plates by using capillary tubes and developed in a TLC chamber using suitable mobile phase. TLC was carried out to study the principle components that were present in ethyl acetate extract of tuber. The different solvent systems of different polarities were prepared, and TLC studies were carried out to select the solvent system capable of showing better resolution. The best separation of the compound in the system of methanol:toluene:ethyl acetate is 7:3:1. The developed TLC plates were air dried and observed under ultra violet light (UV) at both $25 \mathrm{~nm}$ and $366 \mathrm{~nm}$. They were later placed in a hot air oven for $1 \mathrm{~min}$ for the development of color in separated bands. The movement of the solvent was expressed by its retention factor (Rf).

Values were calculated for a different sample

$$
\text { Retention factor }(\mathrm{Rf})=\frac{\text { Distance travelled by solute }}{\text { Distance travelled by solvent }}
$$

After drying the plates, they were exposed to iodine vapors by placing them in a chamber that was saturated with iodine vapors and also exposed to different spraying reagents. All plates were visualized directly after drying and with the help of UV at $254 \mathrm{~nm}$ and $366 \mathrm{~nm}$ in UV chamber. The $\mathrm{Rf}$ value of the different pots that were observed was calculated.

\section{HPTLC analysis}

The ethyl acetate extract was applied on HPTLC (Camag, Switzerland) aluminum sheet pre-coated with silica gel (Merck, silica gel 60 F254 plate, $0.25 \mathrm{~mm}$ ) was used as the adsorbent. Methanol:toluene:ethyl acetate (7: 3:1) was used as the mobile phase. The chromatographic 
development chamber was saturated with mobile phase for $10 \mathrm{~min}$ prior to placement of the plates. The plates were run up to $8-\mathrm{cm}$ height. The plates were dried with dryer for 3-4 min and bands were observed and scanned at $366 \mathrm{~nm}$ and photographs were taken for record.

\section{Gas chromatography-mass spectrometry (GC-MS)}

The GC-MS analysis was done by electron impact ionization (EI) method on Auto system XL gas chromatography (Perkin Elmer Instrument, Germany) coupled to a Turbo Mass Spectrophotometer (Perkin Elmer Instrument, Germany) at Sophisticated and Instrumentation Centre for Applied Research and Training (SICART), Vallabh Vidyanagar, Gujarat. The column was fused silica capillary column, $30 \times 0.25 \mathrm{~mm}$ ID; coated with D-I, 0.25 $\mu \mathrm{m}$ film thickness. The temperature of the column was programmed at 70 to $250^{\circ} \mathrm{C}$ at the rate of $10^{\circ} \mathrm{C} / \mathrm{min}$ increase, injection port temperature at $250^{\circ} \mathrm{C}$. Helium was used as carrier gas at constant pressure of $100 \mathrm{kpa}$ and flow rate of $20 \mathrm{ml} / \mathrm{min}$. Samples which dissolved in methanol was run fully at range of 60-550 amu and the results were compared by using NIST 107 Spectral library search programme.

\section{Statistical analysis}

Data were analyzed by SPSS software (Statistical Package for Social Science, version 20, IBM Corporation, Armonk, NY, USA) and presented as mean \pm S.D. Here, $P$ values less than $0.05,0.01$, and 0.001 were considered as statistically significant.

\section{Results}

\section{Extraction yield (\%) of C. epigaeus tuber}

Powder of C. epigaeus tuber was extracted using different solvents via hot extraction method, i.e., the Soxhlet extraction. Extraction \% yield and weight of extract is shown in Table 1 . Maximum \% yield of extract was obtained in ethyl acetate extract, i.e., $4.46 \%$ and minimum \% yield of extract was obtained in chloroform, i.e., $2.26 \%$.

\section{In-vitro anthelminthic activity of $C$. epigaeus tuber}

Helminthiasis or infections with parasitic worms are pathogenic for human beings. Immature forms of the parasites invade human beings via the skin or gastrointestinal tract (GIT) and evolve into well-differentiated adult worms that have characteristic tissue distribution.

Table 1 Extraction yield (\%) of C. epigaeus tuber

\begin{tabular}{llll}
\hline Solvent & Colour & Weight of extract (g) & Yield \% \\
\hline Methanol & Brownish black & 1.607 & 4.02 \\
Chloroform & Light brown & 1.051 & 2.62 \\
Ethyl acetate & Reddish brown & 1.783 & $\mathbf{4 . 4 6}$ \\
Hexane & Yellowish & 1.557 & 3.89 \\
\hline
\end{tabular}

C. epigaeus tuber was sequentially extracted using different solvents such as methanol, chloroform, ethyl acetate, and hexane. Normal saline solution taken as a control to treat the earthworms (Pheretima posthuma). They remained active for more than $8 \mathrm{~h}$ with good body movement.

\section{Anthelmintic activity of different extract and standard drug} Methanolic extract of $C$. epigaeus plant in concentrations $25,50,75$, and $100 \mathrm{mg} / \mathrm{ml}$ showed paralysis of worms within 1 to $2 \mathrm{~min}$ and death within 3 to $4 \mathrm{~min}$ depending on the concentration (Table 2). Chloroform extract of C. epigaeus plant of concentrations $25,50,75$, and $100 \mathrm{mg} / \mathrm{ml}$ showed paralysis of worms within 4 to 6 min and death within 10 to $13 \mathrm{~min}$ depending on the concentration (Table 2). Ethyl acetate extract of C. epigaeus plant of concentrations $25,50,75$, and $100 \mathrm{mg} / \mathrm{ml}$ show paralysis within 1 to $2 \mathrm{~min}$ and death within 3 to 4 min (Table 2). More time was taken by hexane extract that at concentrations $25,50,75$, and $100 \mathrm{mg} / \mathrm{ml}$, showed paralysis of worms within 6 to $7 \mathrm{~min}$ and death within 10 to $12 \mathrm{~min}$ (Table 2). The standard drug, albendazole showed paralysis at $15.30 \mathrm{~min}$ and death after $34.18 \mathrm{~min}$ at $20 \mathrm{mg} / \mathrm{ml}$ concentration (Table 2).

\section{Effect of different concentrations of ethyl acetate extract}

The ethyl acetate extract was used for the effective dose estimation. It was observed that the ethyl acetate extract of Corallocarpus epigaeus tuber is more potent than the methanol, chloroform, and hexane extracts and their activities were comparable with the standard drug albendazole $(20 \mathrm{mg} / \mathrm{ml})$. The result in the Table 3 depicts the time taken for paralysis and death of worms when treated with different concentrations. Effective dose estimation of C. epigaeus tuber ethyl acetate extract of different concentrations of $1,2,5,10$, and $12.5 \mathrm{mg} / \mathrm{ml}$ dose paralysis (min) and death ( $\mathrm{min}$ ) of 7.40, 7.31, 6.43, 5.47, 3.27 and $11.30,10.74,10.3,8.50,5.84$, respectively.

\section{Phytochemical analysis of quantitative assay of C. epigaeus}

The amount of total phenol was determined with the Folin-Ciocalteu reagent. Gallic acid was used as a standard compound and the total phenols were expressed as milligram per gram gallic acid equivalent using the standard curve equation $y=0.0061 x+0.0396, R^{2}=0.996$, where $y$ is the absorbance at $765 \mathrm{~nm}$ and $x$ is the total phenolic content $(\mathrm{mg} / \mathrm{g})$.

The amount of total flavonoid was determined using the aluminum chloride method. Quercetin was used as a standard compound and the total flavonoid were expressed as milligram per gram quercetin equivalent using the standard curve equation: $y=0.0061 x+0.0396$, 
Table 2 Anthelmintic activity with different extracts of C. epigaeus tuber and standard drug

\begin{tabular}{|c|c|c|c|c|c|c|c|c|c|c|}
\hline \multirow[t]{2}{*}{$\begin{array}{l}\text { Concentration } \\
(\mathrm{mg} / \mathrm{ml})\end{array}$} & \multicolumn{2}{|l|}{ Methanol } & \multicolumn{2}{|l|}{ Chloroform } & \multicolumn{2}{|l|}{ Ethyl acetate } & \multicolumn{2}{|l|}{ Hexane } & \multicolumn{2}{|c|}{$\begin{array}{l}\text { Standard drug } \\
\text { albendazole }\end{array}$} \\
\hline & $\begin{array}{l}\text { Paralysis } \\
\text { (Mean } \pm \text { SD) } \\
\text { (min) }\end{array}$ & $\begin{array}{l}\text { Death } \\
\text { (Mean } \pm \\
\text { SD) (min) }\end{array}$ & $\begin{array}{l}\text { Paralysis } \\
\text { (Mean } \pm S D) \\
(\mathrm{min})\end{array}$ & $\begin{array}{l}\text { Death } \\
(\text { Mean } \pm \text { SD) } \\
(\text { min) }\end{array}$ & $\begin{array}{l}\text { Paralysis } \\
\text { (Mean } \pm \text { SD) } \\
\text { (min) }\end{array}$ & $\begin{array}{l}\text { Death } \\
\text { (Mean } \pm \\
\text { SD) (min) }\end{array}$ & $\begin{array}{l}\text { Paralysis } \\
\text { (Mean } \pm S D) \\
\text { (min) }\end{array}$ & $\begin{array}{l}\text { Death } \\
\text { (Mean } \pm \\
\text { SD) (min) }\end{array}$ & $\begin{array}{l}\text { Paralysis } \\
\text { (Mean } \pm \text { SD) } \\
(\min )\end{array}$ & $\begin{array}{l}\text { Death } \\
\text { (Mean } \pm \\
\text { SD) (min) }\end{array}$ \\
\hline 25 & $2.06 \pm 0.09$ & $\begin{array}{l}4.38 \pm \\
0.19\end{array}$ & $6.19 \pm 0.13$ & $\begin{array}{l}13.74 \pm \\
0.66\end{array}$ & $2.06 \pm 0.09$ & $\begin{array}{l}4.38 \pm \\
0.19\end{array}$ & $7.77 \pm 0.43$ & $\begin{array}{l}12.94 \pm \\
1.27\end{array}$ & $\begin{array}{l}15.28 \pm \\
0.58\end{array}$ & $\begin{array}{l}34.18 \pm \\
0.83\end{array}$ \\
\hline 50 & $1.54 \pm 0.18$ & $\begin{array}{l}4.14 \pm \\
0.12\end{array}$ & $5.40 \pm 0.04$ & $\begin{array}{l}13.47 \pm \\
0.67\end{array}$ & $1.54 \pm 0.18$ & $\begin{array}{l}4.14 \pm \\
0.12\end{array}$ & $7.29 \pm 0.25$ & $\begin{array}{l}13.54 \pm \\
1.31\end{array}$ & $\begin{array}{l}14.11 \pm \\
0.50\end{array}$ & $\begin{array}{l}33.10 \pm \\
0.97\end{array}$ \\
\hline 75 & $1.49 \pm 0.43$ & $\begin{array}{l}3.84 \pm \\
0.11\end{array}$ & $5.03 \pm 0.21$ & $\begin{array}{l}11.60 \pm \\
\text { v1.49 }\end{array}$ & $1.49 \pm 0.43$ & $\begin{array}{l}3.84 \pm \\
0.11\end{array}$ & $6.67 \pm 0.19$ & $\begin{array}{l}11.32 \pm \\
0.39\end{array}$ & $\begin{array}{l}14.24 \pm \\
0.14\end{array}$ & $\begin{array}{l}27.81 \pm \\
0.71\end{array}$ \\
\hline 100 & $1.27 \pm 0.42$ & $\begin{array}{l}3.26 \pm \\
0.19\end{array}$ & $4.75 \pm 0.09$ & $\begin{array}{l}10.06 \pm \\
0.60\end{array}$ & $1.27 \pm 0.42$ & $\begin{array}{l}3.84 \pm \\
0.11\end{array}$ & $6.08 \pm 0.22$ & $\begin{array}{l}10.28 \pm \\
0.11\end{array}$ & $\begin{array}{l}15.16 \pm \\
0.09\end{array}$ & $\begin{array}{l}27.18 \pm \\
0.54\end{array}$ \\
\hline
\end{tabular}

$R^{2}=0.996$, where $y$ is the absorbance at $510 \mathrm{~nm}$ and total flavonoid content is expressed in milligram per gram.

The quantitative estimation of alkaloids was done using Harborne's method (Harborne 1973) and the yield of alkaloid was calculated by back calculation; the yield obtained from ethyl acetate extract of alkaloid was $44.3 \%$ (Table 4).

The quantitative estimation of saponins was done and the yield of saponin was calculated by back calculation; the yield obtained from ethyl acetate extract of saponins was $1.78 \%$ (Table 4 ).

\section{Thin-layer chromatography of ethyl acetate extract of C. epigaeus tuber}

The ethyl acetate extract showed four major bans present in the solvent system of toluene:methanol:ethyl acetate $(8: 2: 1)$. The $\mathrm{Rf}$ values of the bands are $0.53,0.18$, 0.98 , and 0.24 . For the presence of compounds and constituents, using sulphuric acid (H2SO4) and Dragendorff's reagent indicate the presence of cardiac glycoside and alkaloid, respectively.

HPTLC profile of ethyl acetate extract of C. epigaeus tuber HPLC analysis of ethyl acetate extract of $C$. epigaeus tuber has been shown in Fig. 2. The peak no. 2 exhibited maximum percentage area which was $56.00 \%$, and minimum percentage area was present in peak no. 1 which was $0.98 \%$. The area of peak no. 2 is 56.00 and height is

Table 3 Effective dose estimation of ethyl acetate extract of $C$. epigaeus tuber

\begin{tabular}{lll}
\hline Concentration & Paralysis $(\mathrm{min})$ & Death $(\mathrm{min})$ \\
\hline $1 \mathrm{mg} / \mathrm{ml}$ & 7.40 & 11.30 \\
$2 \mathrm{mg} / \mathrm{ml}$ & 7.31 & 10.74 \\
$5 \mathrm{mg} / \mathrm{ml}$ & 6.43 & 10.3 \\
$10 \mathrm{mg} / \mathrm{ml}$ & 5.47 & 8.50 \\
$12.5 \mathrm{mg} / \mathrm{ml}$ & 3.27 & 5.84 \\
\hline
\end{tabular}

20.8. The peak no. 2 is of the chemical constituent that is majorly present in the extract (Fig. 3).

\section{GC-MS of ethyl acetate extract of $C$. epigaeus tuber}

GC-MS analysis of ethyl acetate extract of $C$. epigaeus tuber is shown in Fig. 4. The separation techniques coupled with GC-MS allowed successful separation of constituents as shown in the GC-MS TIC trace in Fig. 4. Identifications of phytochemical compounds were based on the peak area, retention time, and molecular formula. The GC-MS data can be used to identify major bioactive, phytochemical constituent corresponding to major peak with an area of $28.06 \%$. The peak shows maximum percentage area at RT 20.191 in GC-MS analysis and scan $1.25 \mathrm{e} 7$ through mass spectrophotometry. Based on the mass spectrophotometer predication, two compounds majorly identified are $n$-hexadecanoic acid and octadecanoic acid (Fig. 5) present in the ethyl acetate extract of $C$. epigaeus tuber.

\section{Discussion}

Helminths are parasitic worms. They are the most common infectious agents of humans in developing countries and produce a global burden of disease. Helminth infections are commonly found in villages of developing countries and are being recognized as cause of much acute as well as chronic illnesses among humans (Peter et al., 2008; Nisha et al., 2012). Many helminth infections occur in poverty-stricken and developing countries with warm, moist environments and poor sanitary conditions (Peter et al., 2007). Although helminth infections can affect anyone, children in developing nations are mostly at

Table 4 Yield of different components present in the ethyl acetate extract of $C$. epigaeus tuber

\begin{tabular}{llllll}
\hline Extract & $\begin{array}{l}\text { Chemical } \\
\text { components }\end{array}$ & Alkaloid & Phenol & Flavonoid & Saponin \\
\hline Ethyl & Content $(\mathrm{g})$ & $\mathbf{4 4 . 3}$ & $\mathbf{0 . 0 0 1 8}$ & $\mathbf{0 . 3 4 1}$ & $\mathbf{0 . 7 1 3 2}$ \\
acetate & \% Yield & $\mathbf{4 4 . 3}$ & $\mathbf{0 . 0 0 5 0}$ & $\mathbf{0 . 8 5 2}$ & $\mathbf{1 . 7 8}$ \\
\hline
\end{tabular}




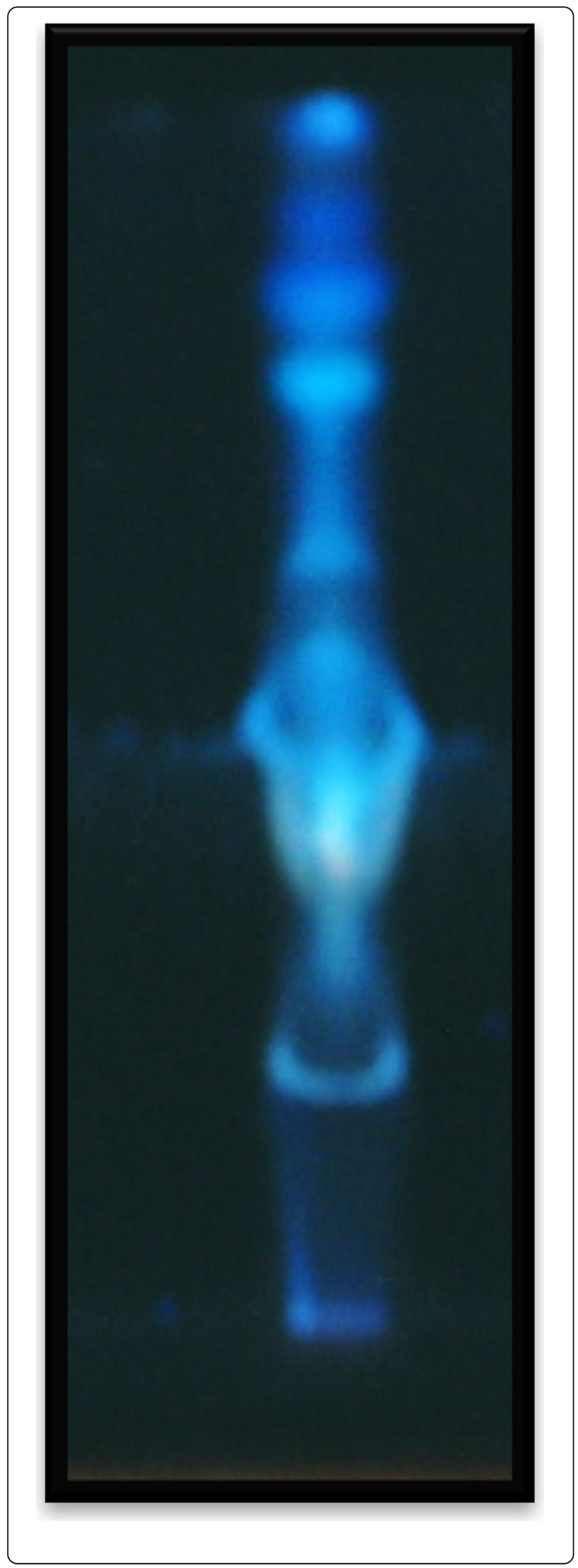

Fig. 2 HPTLC analysis of ethyl acetate extract of $C$. epigaeus tuber

risk (Peter et al., 2008). The World Health Organization reports a $35 \%$ infection rate for roundworm, which is a common parasitic worm (Perry et al., 2002; Krishnamurthi, 2003). These infections are usually transmitted through contaminated soil, food, or water; feces; and unwashed hands or contact with a contaminated object.

Chemical control of helminthes coupled with improved management has been the important worm control strategy throughout the world. However, increasing problems of development of resistance in helminthes (Gilbert, 1996; Coles, 1997). Hence, the best alternative is plant-based medicine. Plants continue to be an important source for identification of new drug. Important plant-derived drugs are still obtained commercially by extraction from their whole plant sources. Plant produces a large number of secondary metabolites that may serve as future reservoir for novel drugs and therapeutic agents. Screening and proper evaluation of the claimed medicinal plants could offer possible alternatives that may be both sustainable and environmentally acceptable. Development of anthelmintic resistance and high cost of conventional anthelmintic drugs led to the evaluation of medicinal plants which are an alternative source of anthelmintics.

Before evaluating the anthelmintic activity, knowledge about the yield of extract is important. Lower extract yielding plants are not commonly preferred by the pharmaceuticals industry. Ishnava et al. (2015) reported that the same plant methanol extract showed maximum extraction yield (3.28\%); compared to our study, the maximum extraction yield (\%) of extract was obtained in ethyl acetate $(4.46 \%)$. This may be due to improper selection of solvent system and method of extraction, using ethyl acetate and collection of our sample from semi deciduous forest of Gujarat. Environmental factors of soil and the location of plant also play significant roles.

Methanolic extract of $C$. epigaeus plant in concentrations 25, 50, 75, and $100 \mathrm{mg} / \mathrm{ml}$ showed paralysis of worms within 1.27 to $2.06 \mathrm{~min}$ and death within 3.26 to $4.38 \mathrm{~min}$ depending on the concentration (Table 2). Nisha et al. (2012) reported that the methanol extract of Pyrostegia venusta at the concentration of $5 \mathrm{mg} / \mathrm{ml}$ showed time of paralysis and death at 65 and $88 \mathrm{~min}$, respectively. For concentrations at $7.5,10$, and $12.5 \mathrm{mg} / \mathrm{ml}$, paralysis was shown at 70,66 , and $34 \mathrm{~min}$, respectively. and death occurred at 94, 91, and $78 \mathrm{~min}$, respectively. Compared to this result, methanol extract of C. epigaeus showed better activity, and in short time, death was observed because concentration is very high.

Chloroform extract of C. epigaeus plant of concentrations $25,50,75,100 \mathrm{mg} / \mathrm{ml}$ showed paralysis of worms within 4.75 to $6.19 \mathrm{~min}$ and death within 10.06 to13.7 


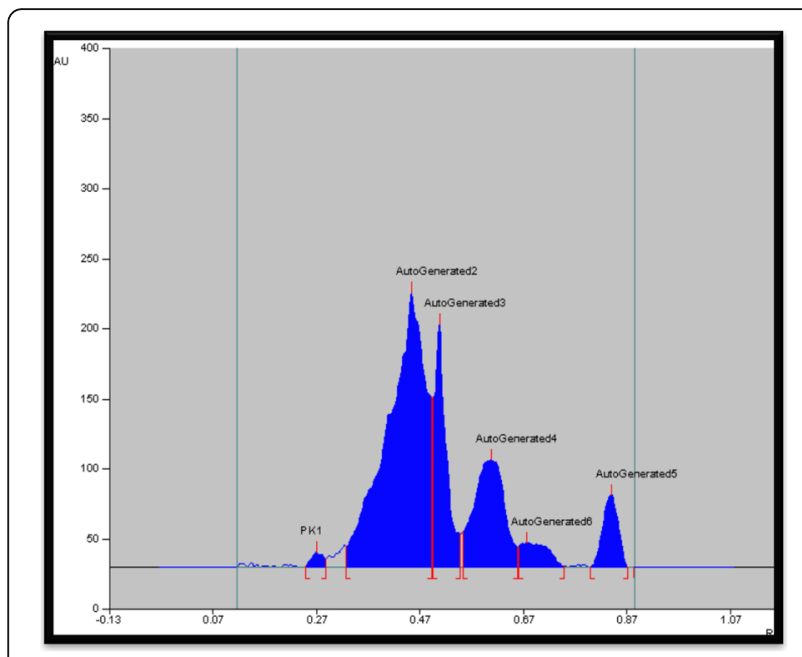

Fig. 3 Profile of ethyl acetate extract of different chemical constituent peaks min depending on the concentration (Table 2). Vidyadha et al. (2010) reported the chloroform extract of Enicostemma littorale at the concentration of $25 \mathrm{mg} / \mathrm{ml}$ showed the time of paralysis and death at 45 and 59 min, respectively. Compared to this study, chloroform extract of C. epigaeus showed better result.

Ethyl acetate extract of $C$. epigaeus plant of concentrations $25,50,75$, and $100 \mathrm{mg} / \mathrm{ml}$ showed paralysis of worms within 1.27 to $2.06 \mathrm{~min}$ and death within 3.84 to $4.38 \mathrm{~min}$ (Table 2). Vidyadha et al. (2010) reported that the ethyl acetate extract Enicostemma littorale at the concentrations of 25,50 , and $100 \mathrm{mg} / \mathrm{ml}$ showed the time of paralysis and death at 35,27, 20 and 49, 39, $27 \mathrm{~min}$, respectively. Compared to this study, ethyl acetate extract of $C$. epigaeus showed paralysis and death at 2, 1.5, 1.2 and 4.3, 4.1, $3.26 \mathrm{~min}$ respectively. This result of $C$. epigaeus shows good activity compared to Enicostemma littorale.

More time was taken by hexane extract; at concentrations $25,50,75$, and $100 \mathrm{mg} / \mathrm{ml}$, it showed paralysis of worms within 6.08 to $7.77 \mathrm{~min}$ and death at 10.28 to 12.94

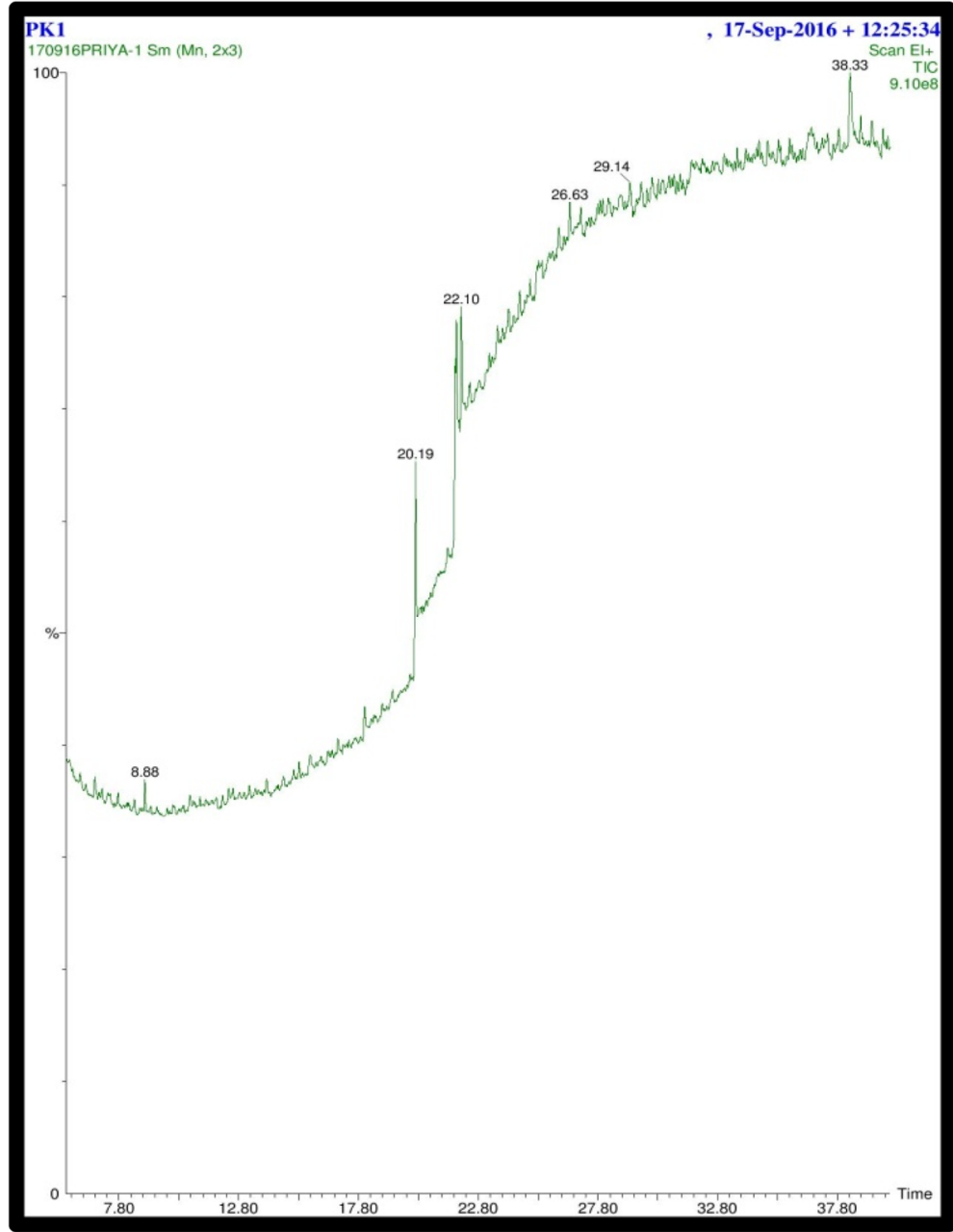

Fig. 4 GC-MS analysis of ethyl acetate extract of C. epigaeus tuber chromatogram (Scan El+ TIC 9.10eB) 


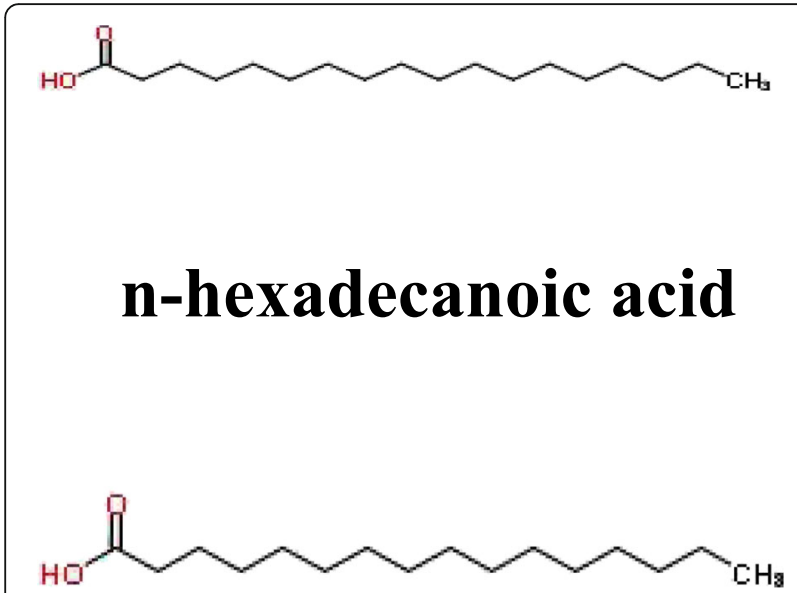

\section{Octadecanoic acid}

Fig. 5 Structure of $n$-hexadecanoic acid and octadecanoic acid

min (Table 2). Vidyadha et al. (2010) reported the hexane extract of Enicostemma littorale at the concentration of 25 and $100 \mathrm{mg} / \mathrm{ml}$ showed the time of paralysis and death at 50, 36 and 64, $49 \mathrm{~min}$, respectively. Compared to this study, C. epigaeus showed paralysis and death at 7.7, 6.08 and 12.94, $10.28 \mathrm{~min}$, respectively. This result shows C. epigaeus' good activity compared to Enicostemma littorale. It can be tested for use as an alternative drug.

The standard drug, albendazole showed paralysis at $15.30 \mathrm{~min}$ and death after $34.18 \mathrm{~min}$ at $20 \mathrm{mg} / \mathrm{ml}$ concentration (Table 2). From the above result, it is clear that all the extracts of $C$. epigaeus plant have significant anthelmintic activity in a dose-dependent manner when compared with standard anthelmintic drug. But ethyl acetate extract showed great results as time taken for death is comparatively very low as compared to standard drug. Vijaya et al. (2011) reported that the same plant using the solvent of ethanolic and aqueous extract compared to the ethyl acetate extract showed great results as time taken for death is comparatively very low. The best solvent is ethyl acetate extract since it gives the best response for a short time and at a minimum dose.

In our study, the effective dose was estimated to be $12.5 \mathrm{mg} / \mathrm{ml}$ as the time of paralysis and death took 3.27 and $5.84 \mathrm{~min}$, respectively. The rest of the concentration took more time for paralysis and death. It caused paralysis followed by death of the worms at all tested dose levels. Potency of the extracts was inversely proportional to the time taken for paralysis death of the worms. It is quite apparent from the studies that the ethyl acetate extract possesses significant anthelmintic activity. The above findings justify the use as an anthelmintic, as suggested in the folklore medicines.

In the qualitative phytochemical analysis of ethyl acetate extract of $C$. epigaeus tuber, various phytoconstituents were present. The ethyl acetate extract showed the presence of alkaloids, tannins, phenol, flavonoid, steroids, saponin, and glycosides. Gnananath et al. (2013) reported that the ethanolic extract of C. epigaeus rhizomes contains phenolic compounds, flavonoids, terpenoids, and phytosterols. Preliminary phytochemical analysis of ethyl acetate extract of C. epigaeus tuber indicated the mix of compounds gives better activity.

Phytochemical constituents of the ethyl acetate extract of C. epigaeus tuber were quantitatively analyzed for the presence of chemical constituents (\%) in the plant under study. The results have been depicted in Table 4. The maximum phytochemical present is alkaloid (44.3\%) in the ethyl acetate extracts (Table 4). The phenol and flavonoid are in relatively less quantity in the ethyl acetate extracts (Table 4). The phenol and flavonoid contents in the standard gallic acid at various concentrations $(\mu \mathrm{g} / \mathrm{ml})$ were obtained (Table 4). The values obtained in the ethyl acetate extract are very less compared to the standard value. Alkaloids are also used as starting materials in the manufacture of steroidal drugs and carry out protective functions in animals, thus are medicinal especially steroidal alkaloids (Maxwell et al., 1995). Isolated pure plant alkaloids and their synthetic derivatives are used as basic medicinal agent for their anthelmintic effects (Gnananath et al., 2013). The presence of these secondary metabolites has contributed to its medicinal value as well as physiological activity (Lewis and Elvin-Lewis., 1977). For instance, phenols have been shown to have antibacterial, anthelmintic, and antineoplastic activities (Alan and Miller., 1996).

HPLC analysis of ethyl acetate extract of C. epigaeus tuber has showed six major peaks. The area of peak no. 2 is 56.00 and height is 20.8. The peak no. 2 is of the chemical constituent that is majorly present in the extract (Fig. 3). Thangavel et al. (2014) reported the same plant collected from Tamilnadu, India using the mobile phase (toluene:methanol (8:2)) separating 11 bands. In our study, a total of 9 bands were obtained in the sample. The plant material is collected from semi-deciduous forest of Gujarat. Environmental factors may have a significant effect on the production of secondary metabolites.

GC-MS analysis of ethyl acetate extract of C. epigaeus tuber identification confirmation was by comparison of their mass spectra with NIST Library version year 2005. Based on the mass spectrophotometer predication, two compounds majorly identified is $n$-hexadecanoic acid and octadecanoic acid (Fig. 5) present in the ethyl acetate extract of C. epigaeus tuber. Moonjit and Himaja (2014) reported that they investigated the insecticidal activity, anthelmintic activity, GC-MS analysis, and the phytochemical 
screening of the petroleum ether (IEP) and ethanol (IEE) extracts of the aerial parts of Ipomoea eriocarpa with the presence of hexadecanoic acid and octadecanoic acid. Alby and Regi (2016) reported the phytochemical studies portray the presence of several biologically active secondary metabolites and GC-MS profiling of B. phoenicea ethanolic extract revealed the presence of possible compounds in the plant are hexadecanoic acid and octadecanoic acid. Dubal et al. (2013) reported the components present in the methanolic extract of rhizome of $T$. coadunate were identified by GC-MS analysis as $n$-hexadecanoic acid (Palmitic acid) having antioxidants, hypochloresterolenic, nematicide, pesticide, lubricant, antiandrogenic flavor, and hemolytic properties. Bohm et al. (2016) reported that the anthelmintic activity of the methanolic extract might be attributed to the wide range of chemical classes including octadecanoic acid, oleic acid, $n$-hexadecanoic acid, eicosenoic acid, oleyl alcohol, cyclohexane, and heptadecanoic acid as per the results of GC-MS. Anthelmintic activity of ethyl acetate extract of $C$. epigaeus tuber might be attributed to the wide range of chemical classes including octadecanoic acid, $n$-hexadecanoic acid, and heptadecanoic acid as per the results of GC-MS.

The structure, chemical formula, and molecular weight of $n$-hexadecanoic acid and octa decanoic acid (Fig. 5) that may be the bioactive compound responsible for the anthelmintic activity are stated below:

IUPAC name: $n$-hexadecanoic acid, Chemical formula: C16H32O2, Molecular weight: $256 \mathrm{~g} / \mathrm{mol}$, Boiling point: $351^{\circ} \mathrm{C}$, Melting point: $62.9^{\circ} \mathrm{C}$ and

IUPAC name: octadecanoic acid, Chemical formula: C18H36O2, Molecular weight: $284 \mathrm{~g} / \mathrm{mol}$, Boiling point: $361^{\circ} \mathrm{C}$, Melting point: $69.3^{\circ} \mathrm{C}$.

\section{Conclusion}

In the evaluation of the anthelmintic activity of the C. epigaeus, extraction was done using organic solvents namely methanol, chloroform, ethyl acetate, and hexane against Pheretima posthuma. The result depicted that the ethyl acetate extract showed the finest activity. The minimum inhibition concentration was found out to be $12.5 \mathrm{mg} / \mathrm{ml}$. The preliminary phytochemical qualitative analysis of the ethyl acetate extract showed the presence of alkaloid, flavonoid, saponin, phenol, tannins, and steroids. HPTLC analysis of ethyl acetate extract showed 6 bands. GC-MS results analysis of ethyl acetate extract showed 6 peaks and the majorly identified bioactive compounds were $n$-hexadecanoic acid and octadecanoic acid. These compounds may be useful for the treatment of the helminthiasis. Prior using, further analysis of cytotoxicity is required.

\section{Abbreviations}

GC: MSGas chromatographymass spectrometry; HPTLC: High performance of thin layer chromatography; g: Gram; mg: Milligrams; min: Minutes; ml: Milliliters; Rf: Retardation factor; SD: Standard deviation; TLC: Thin layer chromatography

\section{Acknowledgements}

The authors are thankful and acknowledge the Sophisticated Instrument Centre for Applied Research and Testing (SICART), DST, India for the HPTLC and GC-MS analyses. The authors are also thankful to Charutar Vidya Mandal (CVM), Vallabh Vidyanagar, Gujarat, India and Director of Ashok and Rita Patel Institute of Integrated Studies and Research in Biotechnology and Allied Sciences (ARIBAS), New Vallabh Vidyanagar -388121, Gujarat, India, for providing necessary support research and laboratory facility.

\section{Authors' contributions}

Priya S. Konar did co-operation in the plan of work, field work, chemical analysis, and arrangement of data. Kalpesh B Ishnava did the designing of the work, interpretation of the data and writing the MS. Both authors read and approved the final manuscript.

\section{Funding}

Not applicable

Availability of data and materials

Not applicable

Ethics approval and consent to participate

Not applicable

Consent for publication

Not applicable

\section{Competing interests}

The authors declare that they have no competing interests.

Received: 30 November 2019 Accepted: 13 February 2020

Published online: 04 March 2020

\section{References}

Alan L, Miller ND (1996) Antioxidant flavonoids: structure, function and chemical usage. Alt. Med. Review 1:103-111

Albonico M, Bickle Q, Ramsan M, Montresor A, Lorenzo S, Taylor M (2003) Efficacy of mebendazole and levamisole alone or in combination against intestinal nematode infections after repeated targeted mebendazole treatment in Zanziba. Bull World Health Organ 81(5):342-352

Alby AB, Regi RK (2016) Evaluation of the folk claim and identification of the pharmacological lactive principles in Bauhinia phoenicea leaves. Asian J. Pharm Clin Res 9(4):1-4

Bhavani MB, Leelavathi S (2012) Investigation on in vitro cytotoxic activity of a selected wild cucurbitacea plant Corrallocarpus epigaeus (Hoo.K.) against cancer. Int J Pharm Sci Res 6(8):3554-3557

Bohm C, Gnana S, Amutha S (2016) Evaluation of anthelmintic activity using solvent extract of Padina tetrastromatica in Indian earthworm (Pheretima posthuma). Int J Ther Appl 32:77-80

Chandan HS, Tapas AR, Sakarkar DM (2011) Anthelmintic activity of extracts of Coriandrum sativum linn in Indian earthworm. Int J Phytomed 3:36-40

Chirac P, Torreele E (2006) Global framework on essential health R and D. Lancet 367:1560-1561

Coles GC (1997) Nematode control practices and anthelmintic resistance on British sheep farms. Vet. Research 141:91-93

Dubal KN, Ghorpade PN, Kale MV (2013) Studies on bioactive compounds of Tectaria coadunate (Wall Ex Hook, and Grev.) C. Chr. Asian J. Pharm Clin Res 6(2):186-187

Gilbert AC (1996) Helminths: structure, classification, growth, and development. Medical Microbiology. 4th edition. University of Texas Medical Branch at Galveston.

Gnananath K, Reddy KR, Gudur PK, Bheemanapally K, Karka SR, Avvari SK (2013) Evaluation of antidiabetic activity in Corallocarpus epigaeus rhizomes. Int Curr Pharm J 2(3):53-56

Harborne JB (1973) Phytochemical methods. Chapman and Hall, Ltd, London, pp 49-188 
Hotez PJ, Herricks JR (2015) Helminth elimination in the pursuit of sustainable development goals: a "worm index" for human development. Negl Trop Disease 9(4):e0003618

Ishnava K, Kotadia R, Sandip P (2015) Nutritional properties and chemical composition of Corallocarpus epigaeus (Rottler) Hook. f.: as remedy to control diabetes mellitus. Chiang Mai J Sci 42(4):806-815

Krishnamurthi A (2003) The wealth of India, vol I. CSIR, New Delhi, p 92

Kuldeep S, Rahul D (2013) A review on medicinal plant for treatment of Helminthiasis. World J Pharmacol Res Technol 1(1):1-7

Lewis WH, Elvin-Lewis MPF (1977) Medical botany. Plants affecting man's health. John Wiley and Sons, New York, p 515

Marco A, Peter GS, Andrew H, Hababu MC, Kassim SA, Lorenzo S (1994) A randomized controlled trial comparing mebendazole and albendazole against Trichuris trichiura, and Ascaris lumbricoides and hookworm infections. Trans R Soc Trop Med Hyg 8(5):585-589

Maxwell A, Seepersaud M, Pingal P, Mootoo DR, Reynoids WF (1995) 3-beta amino spirosolane steroidal alkaloids from Solanum triste. J Nat Products 58:625-628

Moonjit D, Himaja M (2014) Phytochemical screening GC-MS analysis and biological activities of Ipomoea eriocarpa leaf extracts. Int J Pharm Pharm Sci 6(4):592-594

Nisha PV, Shruti N, Sweta SK, Meera K, Vedamurthy AB, Krishna V, Hoskeri JH (2012) Anthelmintic activity of Pyrostegia venusta using Pheretima posthuma Int J Pharm Sci Drug Res 4(3):205-208

Pandey CN, Raval BR, Mali S, Salvi H (2005) Medicinal plants of Gujarat, Gujarat education and research (geer) foundation. Gandhinagar:1-5

Parekh J. Chanda SV (2008) In vitro antimicrobial and phytochemical analysis of some Indian medicinal plants. Turk.J Biot 8; 31:53-58

Perry BD, Randolph TF, McDermott JJ, Sones KR, Thornton PK (2002) Investing in animal health research to alleviate poverty. International Livestock Research Institute (ILRI). Nairobipp:148-149

Peter JH, David HM, Alan F, Jacob K, Sonia ES, Jeffrey DS, Lorenzo S (2007) Control of neglected tropical diseases. N. Engl. J. Med 357:1018-1027

Peter JH, Paul JB, Jeffrey MB, Charles HK, Edward JP, Julie J (2008) Helminth infections: the great neglected tropical diseases. Am Soc Clin Invest 118:1311-1321

Priyavardhini S, Vasantha K, TresinaSoris P, Mohan VR (2012) Efficacy of phytochemical and antibacterial activity of Corallocarpus epigaeus Hook.f. Int J Pharm Tech Res 4:35-43

Robert B, Maria VJ, Jürg U (2009) Diagnostic dilemmas in helminthology: what tools to use and when? Trends in Parasitology 25(4):151-156

Stephenson LS, Latham MC, Kurz KM, Kinoti SN, Brigham H (1989) Treatment with a single dose of albendazole improves growth of Kenyan schoolchildren with hookworm, Trichuris trichiura, and Ascaris lumbricoides infections. Am J Tropical Med Hygiene 41(1):78-87

Subha R, Dinesh KK, Ajaykumar SR (2006) Streblus asper Lour. (Shakhotaka): a review of its chemical, pharmacological and ethnomedicinal properties. Adv Access Publication 3(2):217-222

Thangavel A, Jayaseelan M, Thangaraj N (2014) Evaluation of antioxidant and anti-inflammatory activities of Corallocarpus epigaeus (Hook.F.) rhizomes. Int J Res Pharm Biomed Sci5(1):18-24.

Vasantha K, Priyavardhini S, Tresina SP, Mohan VR (2012) Antifungal activity of Corrallocarpus epigaeus (Hoo.K.) against cancer. Biosci Discov 3(1):87-90

Vidyadha S, Saidulu M, Gopal TK, Chamundeeswari D, Umamaheswara R, David (2010) In vitro anthelmintic activity of the whole plant of Enicostemma littorale by using various extracts. Int J Appl Biol Pharm Technol 1(3):1119-1125

Vijaya SK, Senthamarai TR, Vasuki K, Venkateswara AR, Selvadurai S (2011) Anthelmintic activity of roots and rhizomes of Corallocarpus epigaeus. J. Nat. Prod. Plant Resource 1(1):81-84

WHO (2016) World Health Organization (WHO). Soil-transmitted helminth infections. Fact sheet.www.who.int.

\section{Publisher's Note}

Springer Nature remains neutral with regard to jurisdictional claims in published maps and institutional affiliations.

\section{Submit your manuscript to a SpringerOpen ${ }^{\circ}$ journal and benefit from:}

- Convenient online submission

- Rigorous peer review

- Open access: articles freely available online

- High visibility within the field

- Retaining the copyright to your article

Submit your next manuscript at $\boldsymbol{\nabla}$ springeropen.com 